\title{
Pelatihan Pembuatan Video Pembelajaran Bagi Siswa Tingkat Sekolah Dasar
}

\author{
Tuti Handayani ${ }^{1}$, Alusyanti Primawati ${ }^{2}$, Natalia Tri Astuti ${ }^{3}$ \\ ${ }^{1,2,3}$ Program Studi Teknik Informatika, FTIK, Universitas Indraprasta PGRI \\ Jl. Nangka Raya No. 58C Jagakarsa, Jakarta, Indonesia
}

e-mail: ${ }^{1}$ tuti.hani80@gmail.com, ${ }^{2}$ alus.unindra23@gmail.com, ${ }^{3}$ natnatalia.lia@gmail.com

\begin{abstract}
Abstrak
Pandemi Covid 19 membuka tantangan besar bagi para guru adalah meningkatkan kompetensi memanfaatkan teknologi untuk pembelajaran online atau yang dikenal Pembelajaran Jarak Jauh (PJJ). Kompetensi Guru dan dukungan Orang Tua dalam menyediakan fasilitas pembelajaran online merupakan dua hal penting yang dimungkinkan saling mempengaruhi karena keduanya berdampak pada keberhasilan penyampaian materi ke siswa. Selain Guru dan Orang Tua, siswa merupakan tolok ukur utama dalam suksesnya belajar online. Kemampuan siswa dalam menerima materi belajar dari Guru yang disampaikan secara Daring. Oleh sebab itu, siswa memerlukan motivasi dari Guru melalui kreatifitas Guru dalam menyiapkan bahan ajar yang interaktif. Guru dapat menyediakan alternatif belajar melalui Video Pembelajaran yang menarik bagi siswa dan juga orang tua siswa karena keberadaan orang tua pada saat mendampingi siswa belajar dirumah juga menjadi hal yang penting. Video sebagai media pembelajaran siswa sekolah dasar dinilai efektif untuk meningkatkan kemampuan siswa dalam memahami konsep sehingga meningkatkan motivasi belajar siswa yang disertai dengan meningkatnya hasil belajar siswa selainnya itu Video Pembelajaran juga memenuhi kebutuhan belajar siswa Sekolah Dasar berada pada fase operasional konkret. Berdasarkan hal tersebut maka ditemukan permasalahan para guru di SDN 011 Lenteng Agung memerlukan pelatihan pembuatan Video Pembelajaran bagi siswa tingkat sekolah dasar yang dapat meningkatkan motivasi belajar siswa.
\end{abstract}

Kata Kunci: Guru, Video Pembelajaran, Pembelajaran Jarak Jauh

\begin{abstract}
The Covid-19 pandemic has opened up a big challenge for teachers, which is to increase their competence in utilizing technology for online learning or known as Distance Learning (PJJ). Teacher competence and parental support in providing online learning facilities are two important things that are possible to influence each other because both have an impact on the success of delivering material to students. In addition to teachers and parents, students are the main measure of success in online learning. The ability of students to receive learning materials from teachers delivered online. Therefore, students need motivation from the teacher through the teacher's creativity in preparing interactive teaching materials. Teachers can provide learning alternatives through learning videos that are interesting for students and also parents of students because the presence of parents when accompanying students to study at home is also important. Video as a learning medium for elementary school students is considered effective for improving students' ability to understand concepts so as to increase student learning motivation accompanied by increased student learning outcomes. In addition, learning videos also meet the learning needs of elementary school students who are in the concrete operational phase. Based on this, it was found that the problems of the teachers at
\end{abstract}


SDN 011 Lenteng Agung require training in making Learning Videos for elementary school level students which can increase student's learning motivation.

Keywords: Teacher, Learning Videos, Distance Learning

\section{Pendahuluan}

Pendidikan era Pandemi Covid 19 saat ini berdampak pada semua kalangan baik siswa, guru ataupun orang tua. Salah satu dampak yang dirasakan guru adalah kesulitan beradaptasi dalam menggunakan perangkat teknologi informasi untuk menunjang pembelajaran secara online karena sebelumnya budaya tatap muka, hal ini menjadi tantangan bagi guru karena kompetensi guru dalam menggunakan teknologi akan mempengaruhi kualitas program belajar mengajar yang diselenggarakan secara online (Purwanto et al., 2020). Dampak yang dialami oleh guru memberikan tantangan bagi guru untuk meningkatkan kompetensinya dalam menggunakan perangkat teknologi. Akan tetapi dalam pelaksanaannya perlu fasilitas pendukung untuk memudahkan penyampaian dan penerimaan materi belajar akan tetapi hal ini menjadi kendala utam bagi beberapa sekolah terpencil dan orang tua siswa yang tidak memiliki Smartphone dan keterbatasan ekonomi dalam penyediaan kuota internet (Wulandari et al., 2020).

Kompetensi Guru dan dukungan Orang Tua dalam menyediakan fasilitas pembelajaran online merupakan dua hal penting yang dimungkinkan saling mempengaruhi karena keduanya berdampak pada keberhasilan penyampaian materi ke siswa. Selain Guru dan Orang Tua, siswa merupakan tolok ukur utama dalam suksesnya belajar online. Kemampuan siswa dalam menerima materi belajar dari Guru yang disampaikan secara Daring. Oleh sebab itu, siswa memerlukan motivasi dari Guru melalui kreatifitas Guru dalam menyiapkan bahan ajar yang interaktif. Menurut Srinadi (2015) penggunaan internet saat ini memiliki pengaruh terhadap motivasi belajar siswa karena berdasarkan hasil penelitian bahwa tujuan siswa menggunakan internet adalah jejaring sosial, mengerjakan tugas sekolah, dan Game Online. Saat ini banyak aplikasi belajar online yang bermunculan untuk mendukung kegiatan belajar siswa khususnya tingkat Sekolah Dasar. Biasanya aplikasi belajar online yang digunakan siswa tingkat Sekolah Dasar berfungsi untuk bermain sambil belajar disertai kompetisi antar pengguna sehingga menambahkan motivasi belajar siswa dalam hal wawasan ilmu pengetahuan (Fauzan et al., 2017).

Selain aplikasi berbasis online yang disediakan gratis atau Open Source, media belajar lainnya adalah Video Pembelajaran. Video sebagai media pembelajaran untuk siswa sekolah dasar dinilai efektif untuk meningkatkan kemampuan siswa dalam memahami konsep sehingga meningkatkan motivasi belajar siswa yang disertai dengan meningkatnya hasil belajar siswa selainnya itu Video Pembelajaran juga memenuhi kebutuhan belajar siswa Sekolah Dasar yang berada pada fase operasional konkret (Hadi, 2017). Guru dapat menyediakan alternatif belajar dengan menyediakan Video Pembelajaran yang menarik bagi siswa dan juga orang tua siswa karena keberadaan orang tua pada saat mendampingi siswa belajar dirumah juga menjadi hal yang penting. Selain Guru yang belum melek teknologi, hambatan lainnya adalah kesediaan dan kemampuan orang tua dalam mendampingi anak belajar (Anugrahana, 2020) melalui media yang sudah disediakan Guru seperti Aplikasi atau Video Pembelajaran sehingga menjadi catatan utama juga bagi Guru bagaimana membuat Video Pembelajaran yang mudah dipahami semua kalangan termasuk Orang Tua dan Siswa. Selain itu Video Pembelajaran cukup efektif untuk mengurangi beban kuota bagi Orang Tua dibandingkan dilakukan kelas Zoom atau Google Meet. Seperti yang kita ketahui alternatif lainnya yaitu aplikasi tatap muka daring yang saat ini digunakan untuk memudahkan komunikasi pembelajaran jarak jauh (PJJ) adalah Zoom 
Cloud Meeting, Google Meet dan Aplikasi lainnya (Salsabila et al., 2021), akan tetapi alternatif ini membebankan banyak kuota baik guru ataupun siswa sehingga diperlukan alternatif lainnya seperti Video Pembelajaran yang biasaya dapat diupload oleh Guru melalui media Youtube atau Google Drive sehingga siswa dapat mengulang kembali pembelajaran kapanpun.

Tantangan terbesar adalah guru wajib menyesuaikan diri dengan kemahiran teknologi saat ini sehingga perlu dilakukan peningkatan kemampuan atau kompetensi bagi guru dalam penggunaan teknologi informasi untuk PJJ. Mitra memiliki kebutuhan terhadap pembuatan Video Pembelajaran yang interaktif bagi siswa tingkat Sekolah Dasar sehingga diharapkan Video Pembelajaran dapat meningkatkan motivasi siswa dalam belajar

Berdasarkan latar belakang diatas, maka kami mengusulkan pengabdian masyarakat yang bertema "PKM Kelompok Guru SDN 011 Lenteng Agung" dengan materi "Pelatihan Pembuatan Video Pembelajaran bagi Siswa Tingkat Sekolah Dasar."

Mitra pengabdian masyarakat kami adalah kelompok Guru SDN 011 Lenteng Agung. Bebrapa permasalahan yang sedang dihadapi oleh mitra, diantaranya adalah:

1. Siswa membutuhkan Video Pembelajaran yang interaktif dan mudah dipahami sehingga meningkatkan motivasi belajar siswa

2. Kurangnya pengetahuan guru terhadap aplikasi pembuatan Video Pembelajaran untuk PJJ siswa tingkat Sekolah Dasar.

3. Kurangnya pengetahuan guru terhadap teknik pembuatan Video Pembelajaran untuk PJJ siswa tingkat Sekolah Dasar.

Tujuan dari kegiatan pengabdian masyarakat ini adalah:

1. Meningkatkan kompetensi mitra dalam pembuatan Video Pembelajaran dengan teknik yang tepat.

2. Menambahkan pengetahuan mitra tentang aplikasi yang dapat digunakan untuk mendukung pembuatan Video Pembelajaran yang interaktif bagi siswa tingkat sekolah dasar.

3. Memberikan wawasan kepada mitra tentang dampak Video Pembelajaran yang tepat sehingga meningkatkan motivasi belajar siswa tingkat sekolah dasar.

Kegiatan Pengabdian Masyarakat yang akan kami laksanakan merupakan Program Kemitraan Masyarakat. Mitra sasaran program ini adalah para guru SDN 011 Lenteng Agung yang dilaksanakan dalam bentuk kegiatan pelatihan untuk meningkatkan penggunaan teknologi, yaitu:

1. Pelatihan teknik pembuatan Video Pembelajaran dengan memanfaatkan perangkat teknologi informasi.

2. Penggunaan aplikasi pendukung untuk membuat Video Pembelajaran. 


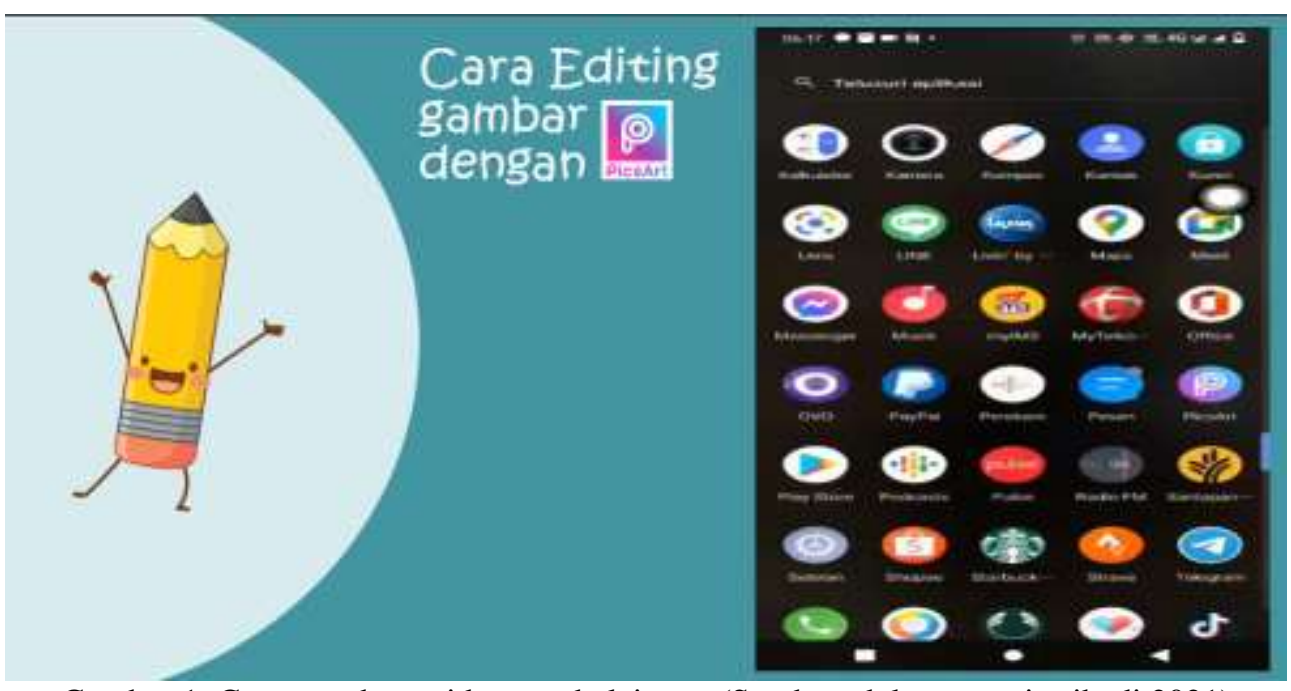

Gambar 1. Cara membuat video pembelajaran. (Sumber: dokumentasi pribadi,2021)

\section{Metode}

Sesuai dengan tujuan pusat pengabdian masyarakat dalam analisis situasi diatas, maka Universitas Indraprasta PGRI sebagai salah satu institusi perguruan tinggi melalui kegiatan pengabdian kepada masyarakat diharapkan dapat berperan aktif dalam menyebarluaskan IbM sebagai produk yang telah diteliti dan dimanfaatkan untuk mencapai sasaran tersebut. Kegiatan pengabdian ini menggunakan metode presentasi, ceramah, diskusi, atau kombinasi antara metode tersebut. Kemudian untuk memperdalam materi diberikan contoh dan dibuka kesempatan untuk tanya jawab bagi peserta pengabdian. Dengan diselenggarakan pelatihan pembuatan Video Pembelajaran melalui teknik-teknik yang tepat dan aplikasi pendukung maka diharapkan mitra akan meningkatkan PJJ menjadi lebih efisien dan materi belajar dapat tersampaikan dengan baik kepada siswa tingkat sekolah dasar.

Metode yang digunakan pada kegiatan pengabdian masyarakat adalah pelatihan pembuatan video pembelajaran melalui Daring dengan tahapan sebagai berikut:

1. Persiapan

Tim menjelaskan kebutuhan yang diperlukan Guru saat ini dalam menghadapi pandemi yaitu pengumpulan mitra yang belum memiliki kemampuan menggunakan komputer atau internet, pengurusan perizinan, mengadakan koordinasi dengan Kepala Sekolah, penyesuaian waktu dengan kelompok sasaran.

2. Koordinasi pelaksanaan melalui Google Meet

Kegiatan pengabdian masyarakat ini dilaksanakan secara daring dengan Google Meet menggunakan metode presentasi, diskusi, atau kombinasi antara metode tersebut pada hari Sabtu, 26 Juni 2021 pada pukul 09.00-11.00 WIB. 


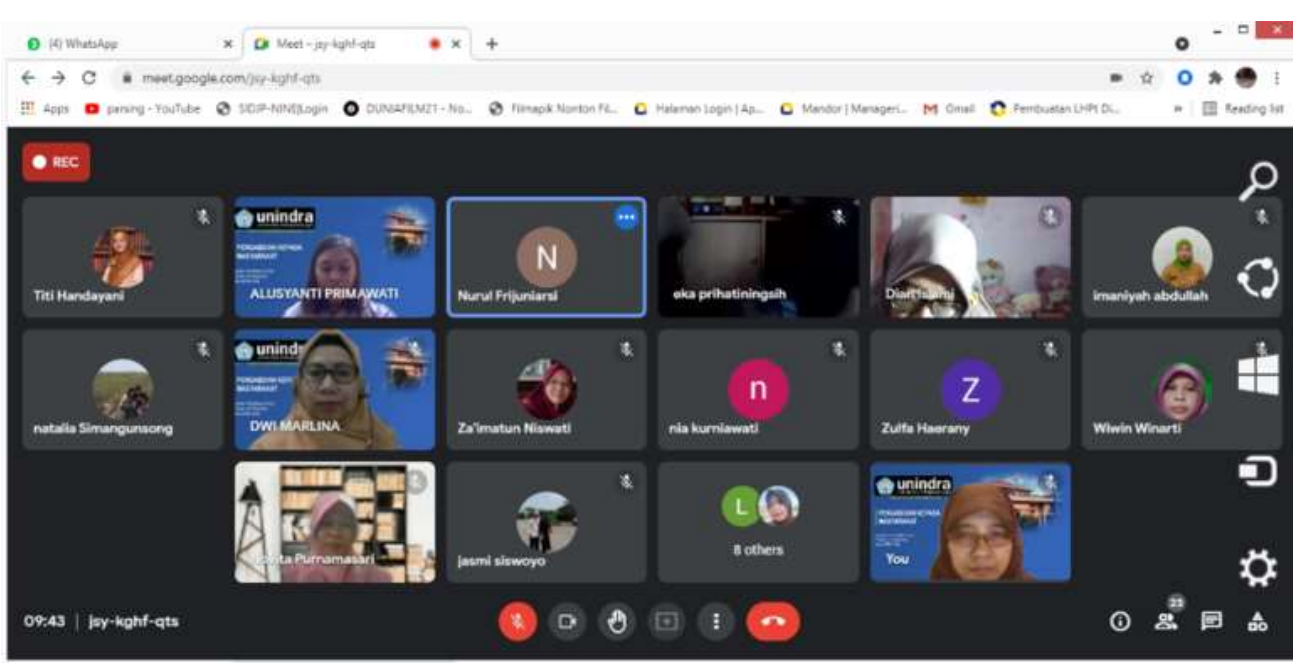

Gambar 2. Peserta yang hadir

3. Sosialisasi Penerapan Video Pembelajaran

Teknik pembuatan Video Pembelajaran untuk PJJ dan penggunaan aplikasi pendukung dalam pembuatan Video Pembelajaran untuk PJJ.

4. Pelatihan Membuat Video Pembelajaran

Pada tahap ini, kami menjelaskan kepada mitra langkah-langkah membuat video, mengedit video dengan aplikasi pendukung.

5. Diskusi

Kami memberikan kesempatan tanya jawab kepada para Guru.

\section{Hasil dan Pembahasan}

Kegiatan pengabdian masyarakat telah terlaksana dengan dihadiri peserta dari mitra SDN 011 Lenteng Agung. Pelaksanaan dilakukan secara daring melalui media Google Meet sebanyak 3 sesi dengan masing-masing sesi memiliki waktu 40 menit. Sesi 1 pemaparan materi dari kami selaku Tim 1 dengan tema tentang pelatihan pembuatan video pembelajaran bagi siswa tingkat sekolah dasar.

Kami memberikan materi mengenai pentingnya menyiapkan bahan ajar yang tidak hanya baik namun juga menarik mengingat saat ini siswa dihadapkan pada sistem pembelajaran jarak jauh (PJJ). Banyak kendala yang terjadi di lapangan selama PJJ, baik dalam hal teknis maupun non teknis, termasuk diantaranya kurangnya minat siswa untuk berpartisipasi dan menyimak materi yang disampaikan oleh guru. Oleh karena itu, guru dituntut untuk dapat menyediakan bahan ajar yang kreatif. Salah satunya dengan membuat video pembelajaran.

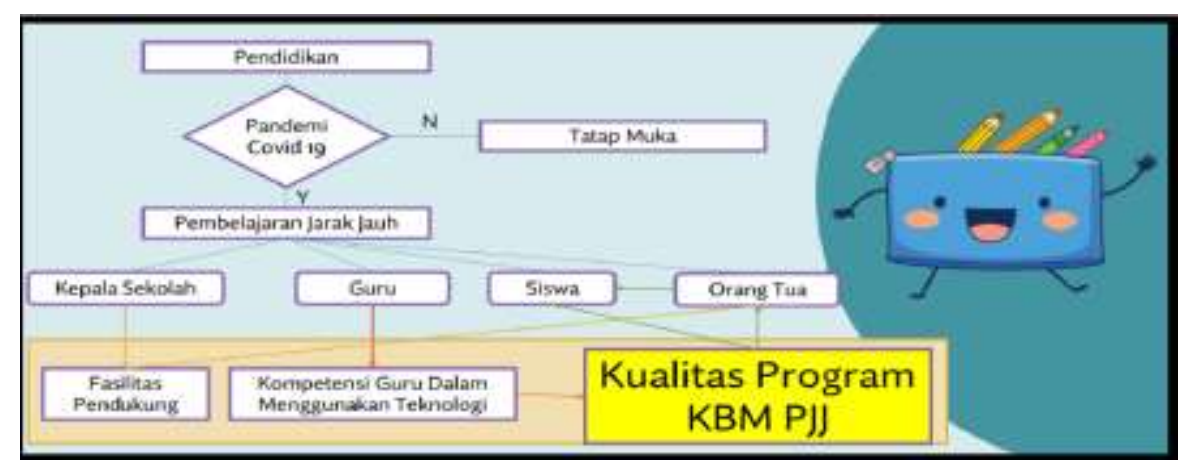

Gambar 3. Pendahuluan permasalahan dan solusi KBM dalam bentuk PJJ

(Sumber: dokumentasi pribadi,2021) 
Setelah menjelaskan permasalahan dan solusi yang diperlukan selama Pembelajaran Jarak Jauh disimpulkan bahwa tujuan utamanya adalah meningkatkan kualitas program KBM PJJ melalui kompetensi Guru dalam menggunakan teknologi. Maka dirumuskan bahwa bagaimana meningkatkan kompetensi Guru dalam mempersiapkan Video Pembelajaran yang interaktif bagi siswa khususnya tingkat Sekolah Dasar.

Pada proses pelatihan, kami memaparkan trik membuat video pembelajaran interaktif yaitu:

1. memilih aplikasi desain seperti Canva, PPT, Piscart, dan lainnya,

2. memilih aplikasi video editing seperti ClipVue dan lainnya,

3. menyediakan perangkat yang mampu menangkap layar atau merekam layar,

4. memilih desain warna dan gambar yang sesuai dan menarik,

5. membuat sistematika KBM PJJ sama seperti KBM tatap muka, misalnya:

a. materi belajar berisi penjelasan langsung dari Guru melalui Video Tutorial,

b. mengadakan kuis atau evaluasi materi dengan menggunakan Google Form atau

Quizizz,

c. Memberikan reward kepada siswa.

Selanjutkan kami menjelaskan langkah-langkah membuat Video Pembelajaran yang interaktif.

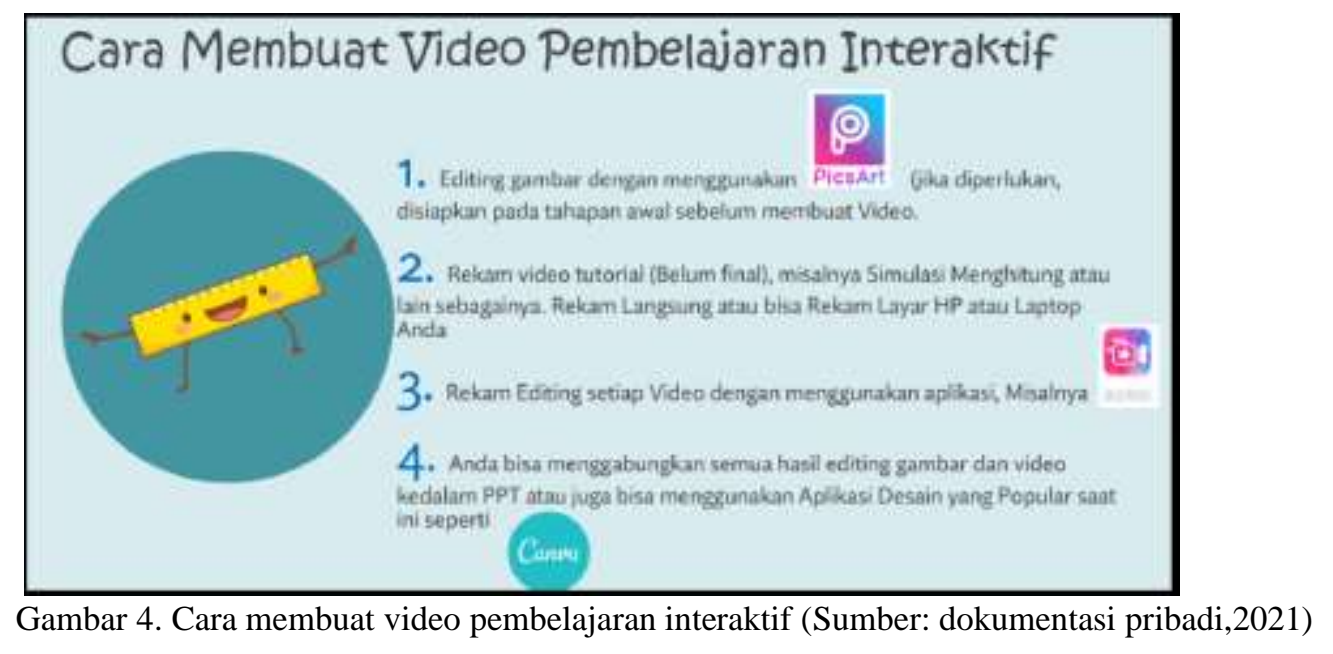

Pada Gambar dijelaskan bahwa langkah awal adalah editing gambar dengan menggunakan aplikasi seperti PiscArt (jika diperlukan dan disiapkan pada tahapan awal sebelum membuat video). Langkah kedua yaitu merekam video tutorial misalnya simulasi menghitung dan lainnya secara langsung atau dapat menggunakan fitur rekam layar pada handphone ataupun laptop. Langkah ketiga adalah melalukan editing video dengan menggunakan aplikasi misalnya CLIPVUE. Selanjutnya langkah terakhir yaitu anda dapat menggabungkan semua hasil editing gambar dan video ke dalam PPT atau aplikasi desain yang popular saat ini seperti CANVA. Semua langkah-langkah kami praktikan dalam pelatihan sehingga mitra mudah memahaminya.

Setelah Video Pembelajaran selesai dibuat maka hal penting selanjutnya adalah mendistribusikan Video Pembelajaran dengan tepat karena biasanya hasil Video Pembelajaran memiliki ukuran data yang besar sehingga diperlukan cara lain seperti:

1. upload ke Google Drive, Share Link, atau 


\section{2. upload ke Channel You Tube dan Share Link.}

Pada akhir materi kami memberikan motivasi bahwa media belajar yang disiapkan dengan tepat dan bukan seadanya akan meningkatkan semangat belajar seseoran sehingga diperlukan sistematika KBM PJJ yang bervariasi untuk meningkatkan kemampuan siswa. Selain itu audio dan visual memiliki kekuatan untuk meningkatkan kemampuan anak. Jumlah guru yang hadir dalam PKM sebanyak 7 Guru. Berikut ini daftar hadir peserta dari Mitra yang hadir dalam PKM.

Tabel 1. Daftar Hadir Mitra

\begin{tabular}{|l|l|l|l|}
\hline No & \multicolumn{1}{|c|}{ Nama } & Peran & \multicolumn{1}{c|}{ Asal } \\
\hline 1. & Jasmi & Guru & SDN 011 Lenteng Agung \\
\hline 2. & Eka Prihatiningsih & Guru & SDN 011 Lenteng Agung \\
\hline 3. & Arti Wiyarni & Guru & SDN 011 Lenteng Agung \\
\hline 4. & Dian Islamiaty Lestari & Guru & SDN 011 Lenteng Agung \\
\hline 5. & Imaniyah & Guru & SDN 011 Lenteng Agung \\
\hline 6. & Eva Kurnia & Guru & SDN 011 Lenteng Agung \\
\hline 7. & Uniy Handayani & Guru & SDN 011 Lenteng Agung \\
\hline
\end{tabular}

Sesi 2 pemaparan materi dari tim 2, yaitu tim pengabdian masyarakat dari Teknik Informatika Universitas Indraprasta dengan tema yang berbeda yaitu pelatihan membuat media pembelajaran interaktif matematika. Sesi 3 merupakan sesi dibukanya diskusi antar mitra dan tim pengabdian masyarakat. Pertanyaan yang diajukan oleh peserta yaitu mengenai teknik penyusunan materi yang tampaknya masih sulit dimengerti, terlebih dalam mengaplikasikan animasi ataupun fitur-fitur terkait bahan ajar. Sebagai respon, pemateri menjelaskan kembali trik-trik dan animasi dasar yang dapat digunakan, langkah dalam meng-input gambar yang dapat berupa gambar maupun foto yang terdapat pada galeri, sesuai dengan kebutuhan bahan ajar.

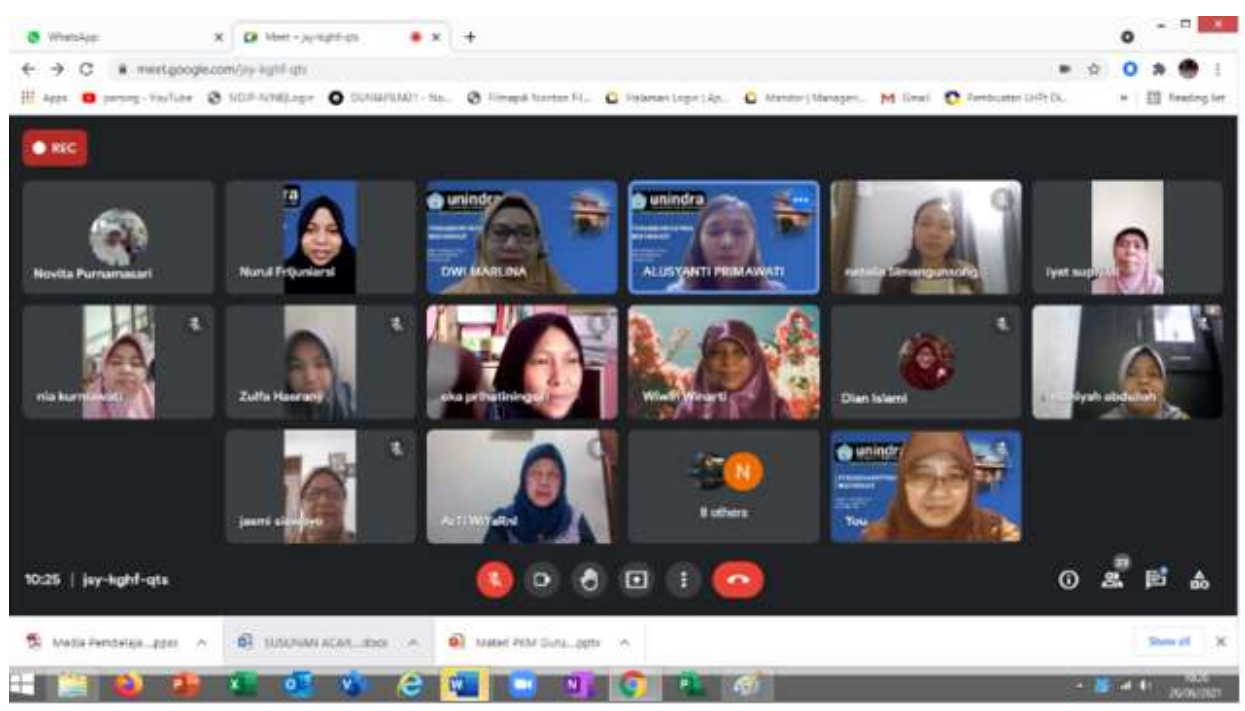

Gambar 5. Sesi Diskusi

Dari hasil kegiatan pengabdian masyarakat ini:

1. Guru mengetahui tahapan pembuatan media belajar,

2. Guru mengetahui aplikasi apa saja yang mudah digunakan untuk mendukung pembuatan media belajar,

3. Guru termotivasi mempersiapkan media belajar yg kreatif dan inovatif sehingga materi 
pembelajaran dapat tersampaikan dengan baik.

\section{Kesimpulan}

Kegiatan pengabdian masyarakat ini telah memberikan kontribusi yang positif bagi peningkatan pengetahuan dan skill dalam bidang teknologi informasi dalam upaya memudahkan kelompok pendidik seperti guru dalam membuat video pembelajaran untuk anak sekolah dasar. Harapannya ilmu ini dapat dipraktekkan oleh para guru untuk membuat video pembelajaran yang menarik dan interaktif. Hal ini guna menarik siswa sekolah dasar dalam mengikuti pelajaran yang dilakukan secara PJJ.

\section{Daftar Pustaka}

Anugrahana, A. (2020). Hambatan, Solusi dan Harapan : Pembelajaran Daring Selama Masa Pandemi Covid-19 Oleh Guru Sekolah Dasar. Scholaria: Jurnal Pendidikan Dan Kebudayaan, 10(3), 282-289.

Fauzan, M. N., Resdiana, W., \& Hamidin, D. (2017). Aplikasi Cerdas Cermat Online Realtime untuk Sekolah Dasar. Jurnal Informatika, 14(1), 22-27. https://doi.org/10.9744/informatika.14.1.22-27

Hadi, S. (2017). Efektivitas Penggunaan Video Sebagai Media Pembelajaran untuk Siswa Sekolah Dasar. Prosiding TEP \& PDs Transformasi Pendidikan Abad 21, 96-102.

Purwanto, A., Pranomo, R., Asbari, M., Santoso, P. B., Mayesti, L., Wijayanti, Hyun, C. C., \& Putri, R. S. (2020). Studi Eksploratif Dampak Pandemi COVID-19 Terhadap Proses Pembelajaran Online di Sekolah Dasar. EduPsyCOuns Journal, 2(1), 1-12.

Salsabila, U. H., Utami, S. N., Zahra, A., Haikal, F., \& Cahyono, A. (2021). Pengaruh Penggunaan Media Belajar Online Selama Pandemi. Jurnal Ilmiah Wahana Pendidikan, 7(1). https://doi.org/10.5281/zenodo.4412063

Srinadi, N. L. P. (2015). Analisis Pengaruh Penggunaan Teknologi Informasi Sebagai Media Pembelajaran Terhadap Motivasi Belajar Siswa. Konferensi Nasional Sistem Dan Informatika 2015, STMIK STIKOM Bali, 9-10.

Wulandari, M. A., Arga, H. S. P., Kelana, J. B., Altaftazani, D. H., \& Ruqoyyah, S. (2020). Analisis Pembelajaran "Daring" Pada Guru Sekolah Dasar di Era COVID 19. Jurnal Imiah UPT P2M STKIP Siliwangi, 7(2), 164-168. 